the National Manpower Commission in regard to a number of industrial relations issues emanating from Part 1 of the Wiehahn Commissions's Report.

In so far as employment is concerned, the National Manpower Commission established a Standing Committee on employment creation at its very first meeting, and directed the committee to study the problem and to submit recommendations to the National Manpower Commission. In order to assist the Standing Committee in its task, the Bureau for Economic Policy and Analysis of the University of Pretoria was requested to conduct an investigation into the problem in its macro and especially its micro-context. The study was completed in August 1980, and the National Manpower Commission has already submitted specific recommendations to the relevant authorities.

In conclusion it should be reiterated that all manpower issues are receiving a great deal of attention in official circles and that a good deal of progress has been made in different fields. Much remains to be done by all parties in volved, namely the Government, employers/employers' organizations and employees/employee organizations. It is for this reason that the Manpower 2000 project was initiated by the Minister of Manpower Utilisation and that informal regional committees have been established in all the larger urban areas in South Africa. These Committees can, it is believed play a very valuable role in regard to manpower matters at local and regional levels, particularly in so far as manpower planning is concerned. In this way, they could well become permanent and important bodies on the local manpower scene, providing information on development possibilities, unemployment, training needs, industrial relations problems etc and becoming actively involved in various action programmes. Employers and workers should be urged to support these committees and to involve themselves actively in the work of these committees.

\section{Development of manpower and training facilities}

\author{
G.W. Ward
}

General Manager, Atlas Aircraft Corporation

\section{Common standards - evaluation of manpower development}

A prerequisite to the management of manpower development is a clear understanding of the business we are in and the business we want to be in.

Common standards that apply to our performance appraisal of manpower development are, inter alia, as follows:

- Adequate forecasting of manpower requirements,

- Setting of realistic manpower objectives,

- Planning in line with set objectives,

- Careful selecting of manpower,

- Educating and training of manpower - off and onthe-job,

- Coaching and counselling of manpower,

- Formulating and implementation of succession plans,

- Reselecting, retraining and on-going development to, and ahead of, need,

- Communication and co-ordination of training requirements with others i.e. 'pooling'.

\section{Measurement against standards}

The question then to be asked of ourselves is where do we stand when measured against such standards both now and in the context of our future plans?

Namely:

- Do we forecast our coming/future requirements?

- Do we set realistic objectives?

- Do we plan our manpower requirements realistically?

- Do we select and re-select our manpower carefully?

- Do we educate and train our manpower - off and on-the-job?

- Do we coach, counsel and further develop our people?

- Do we formulate and implement succession plans?

- Do we communicate and co-ordinate our training plans with others having similar requirements?

i.e. how do we shape up as professionals?

\section{Formulation of company action plans}

Based on the foregoing comparison of our performance against standard, whatever the field(s) of manpower training, and based on the premise 'THAT THE BEST HELP IS SELF HELP', it is essential that we set our priorities, formulate our own action plans and com- 
municate, co-ordinate and implement these where independent or joint benefits may accrue.

When considering overall training effectiveness, certain smaller companies may find it better initially to contract with other larger companies for assistance in basic training in the short-term. In the longer term pooled/other efforts must be considered.

\section{Adequacy of training facilities}

The adequacy of training facilities to meet short-throughlonger-term training needs in the apprentice and associated fields appears to warrant close attention of the Industry collectively, through its member associations' initiative.

As the Industry develops, and quite apart from its own needs for 'all race' training, the opportunity is emerging to render training assistance to business partners in neighbouring Southern African States. This could be undertaken by individual companies independently or via some suitable Industry-owned, or other-owned, centralised basic training centre(s).

Since training schools train first-year apprentices in basics only, and since second and third year apprentices have to be trained on the shop floor, more reliance on Approved Maintenance Organizations (AMO's) is foreseeable and may be considered wise. This is owing to the continuous increase in aircraft sophistication and to the need to have equipped workshops for on-the-job training of second and third year apprentices.

Similar consideration will have to be given to training facility adequacy for training in other key disciplines of the Aviation Industry.

\section{Educational facilities}

Education for the wide field of Aviation in RSA can be split into two main classes viz 'local education' and 'overseas educational' support.

Local institutions viz Technical Colleges, Technicons and Universities have catered reasonably for the basic and general education needs of the past. Ways are expected to be found by Government to allow admission of non-whites to Technical Colleges and other institutions to enable them to obtain the necessary theoretical qualifications required by their chosen disciplines.

Where larger numbers of certain key people have to be trained, the RSA Universities could be expected to take up the challenge and offer selected courses. However, here again, careful determination of the on-going requirement is very essential before committing to a course of action prematurely.

It is accepted that overseas educational support in certain specialized fields will follow normal local academic/ other training for selected key personnel, in the foreseeable future, and until the local requirement grows sufficiently to warrant other arrangements.

Taken overall, and in the longer term, it is foreseen that RSA should, through its training and educational facilities, remain in the fore-front of education on the continent of Africa. The Industry, and training institutions, should plan to entice ever-growing numbers of trainees from their business and other associates throughout Southern Africa.

\section{Methods of training}

Methods of training in some fields appear to need a 'fresh approach'. For example, are we still training by the 'best outmoded methods' or are we 'managing change' in our methods of training?

Do we train people too widely initially at high cost and then use them narrowly and cost-ineffectively, or do we train for specializations and then put people to work and rselect the 'winners' for wider training progressively? The cost reduction impact in such cases can be very high and we would not be falling into the pitfall of possibly overtraining i.e. raising employees' expectations and then succeeding in dissatisfying them and eventually losing them and starting the cycle over again.

This obviously does not apply in all cases but the principles are sound.

The question that remains for us to answer is, 'Whose job is it to review training methods drastically?' The answer perhaps emerges from the parallel, often misunderstood by many of us, viz 'Whose job is it to manage change?' Yes, it is our job and not somebody else's - 'the buck stops here!'

What therefore are we doing about it and/or going to do about it?

\section{Cost of training}

The deliberations made above, lead us to the next question viz 'What is manpower development costing us and what should it cost us?'

It is probably true that it is costing some too much and others too little!

Why then the imbalance and why has it occurred?

It is clear that as long as imbalance exists and costs for some are too high shortages of manpower (in times of increased growth) will occur. We must say 'will occur' because they 'happen to us': we certainly do not 'plan for shortages!'

What then is wrong? We must get back to the standards and questions discussed earlier viz

- Do we understand our business?

- Do we know where we are going?

- Do we set achievable goals?

- Do we plan our resources realistically (including manpower)?

- Do we train professionally?

- Do we plan for succession?

- Do we accept and manage change?

The answers to these questions determine the performance level of our ability of not only managing our business but our most critical of resources viz manpower.

\section{Funding of training/education}

It is clear from the above-mentioned 'higher than necessary' cost of training for some, that a suitable method of spreading training costs is necessary.

Serious attention has been given to manpower development, and its selective funding, by Government and it behoves us to contribute our share in the overall task as it gains momentum.

In the context of funding the training of artisans for the Industry, a feather may be taken from SEIFSA's 
(Steel and Engineering Industries Federation of South Africa) cap where the levy/rebate scheme has operated successfully for many years.

Funding, by the Industry's companies, of selected training or further education for deserving or promising individuals could be enhanced logically via managed manpower development budgets. Full or subsidized costs could be absorbed by the company for training as part of its business expenses if other assistance should not be forthcoming. Further education funding could be similarly absorbed under enhanced bursary etc allocation.

The development of manpower is indeed an investment that yields real returns in the long-range.

Are we all doing our share in this vital area?

\section{Conclusions}

From what we have heard in the past two days proceedings and from the above attempt to bring perspective to our current and hopefully changing attitude, many questions have been raised. If too few answers have been given, then the purpose of this paper has been achieved, since deep deliberation is always necessary before we set objectives involving changing future parameters.

The very human, but perhaps true failing, that most of us, except perhaps the realists, have is that 'change should occur in a nice orderly way, to suit our ends, and preferably without too much effort on our part'.

Is this true, partly true, or is it our job to bear up to the challenges of the future, manage change and set a sound planning base for the future?

\section{National planning perspectives}

\author{
C.F. Scheepers \\ C.F. Scheepers \\ Chief Planner, Prime Ministers Offke
}

\section{Background}

It is well-known that the South African authorities implemented a major new approach to national economic planning about a year ago. This has been a major step an institutional reform - by Government hopefully to put it in a better position to deal with the development issues that will face this country for at least the next decade. The new Economic Development Programme has been restructured to provide Government with a better information background of the major socio-economic trends that will be prevalent in future as well as with the alternative policy strategies and priority areas where action is needed. Probably the most important advantage of the new system of economic planning is that it enables Government to identify more clearly the total cost and benefits of specific actions which are aimed at the attainment of its stated aims. Moreover, the new planning framework that is embodied in the EDP provides Government and the public with a better understanding of the development issues that are at stake which have to be resolved with the limited resources that are available for this purpose. Hopefully this will reduce the danger of over-extending the country's financial resources for socio-economic purposes and avoid the tendency to strive for goals that are either inconsistent with each other or beyond the country's means.

\section{The international background}

There is no doubt that the decade of the eighties and beyond certainly holds exciting economic prospects for a country like South Africa, but one should not underrate the high risks economically and politically that will always be with us. A very important aspect that must be considered for planning purposes over the longer term is in fact the role South Africa envisages itself to fulfil in world perspective. South Africa has always had an open economy and there is no reason to believe that this situation will change drastically in future. We must therefore in formulating our development strategy take cognisance of probable structural changes that will make itself felt in a world context. Obviously, the object of the exercise must be for South Africa through forward planning to capitalize on these developments for the sake of its own national interest and development.

In a global context, South Africa will have to take note of certain expected developments in the international economic field which in many respects are not new but are expected to become more prominent and important from a policy planning point of view. One must remember that South Africa probably holds a unique position in the world today when its own economic structure and involvement in world trade is taken into consideration. It is well-known that the RSA is basically a 